\title{
Groundwater Quality Investigation of the Dammam Unconfined Aquifer, Umaid Area - Muthanna Governorate - Iraq
}

\author{
1Moutaz A.Al-Dabbas, ${ }^{2}$ Yas K. Al-Ameri and ${ }^{3}$ Weam H. Kadhim \\ ${ }^{1}$ College of Science, Baghdad University, Baghdad, Iraq. \\ ${ }^{2}$ General Commission for Groundwater, Ministry of Water Resources, Baghdad, Iraq. \\ ${ }^{3}$ Department of Chemistry, College of Science for girls, Baghdad University, Baghdad, Iraq.
}

Correspondence Author: Moutaz A.Al-Dabbas, College of Science, Baghdad University, Baghdad, Iraq.

E-mail: weamhh99@yahoo.com

Received date: 11 February 2018, Accepted date: 15 May 2018, Online date: 29 May 2018

Copyright: (C) 2018 Moutaz A.Al-Dabbas et al. This is an open-access article distributed under the terms of the Creative Commons Attribution License, which permits unrestricted use, distribution, and reproduction in any medium, provided the original author and source are credited.

\begin{abstract}
Ground water is a vital source for all sectors, agricultural, irrigation sectors and rural communities. The global climate change is expect to change the hydrometeorological processes parameters and it is vital taking into account the groundwater quality investigation that may affect by the global climate change. The groundwater of Dammam unconfined aquifer in Umaid area, Muthanna Governorate, Iraq, was studied to identify the main hydrogeochemical processes and the groundwater-rock interaction. The results indicated that $\mathrm{Ca}^{2+}$ and $\mathrm{SO}_{4}{ }^{2-}$ are the dominant ions in the groundwater. The average contribution of cations in the aquifer is $\mathrm{Ca}^{2+}(18.9 \%), \mathrm{Na}^{+}(18.1 \%), \mathrm{K}^{+}(1.5 \%)$, and $\mathrm{Mg}^{2+}(11.5 \%)$; while anions contribution is $\mathrm{SO}_{4}{ }^{2-}(27.1 \%)$, $\mathrm{Cl}^{-}(18.4 \%)$ and $\mathrm{HCO}_{3}^{-}(4.5 \%)$. The Groundwater characterized by neutral to slightly alkaline hard water, excessively mineralized, and slightly brackish water type. Rock-water interaction processes are identified to include dissolution of carbonates, sulfates, halite, and clay minerals, leaching, and cation exchanges, with little impact of evaporation. The studied groundwater is unsuitable for human drinking purposes, suitable to agricultural most of Fruit crops, vegetable and field crops and suitable for livestock.
\end{abstract}

Key words: Groundwater Quality, Dammam unconfined aquifer, Muthanna, Iraq.

\section{INTRODUCTION}

The effects of the global climate change may expect to change the hydrometeorological processes parameters. Therefore, it is vital taking into account the groundwater quality investigation that may affect by the global climate change due to rock-water interaction processes that include dissolution of carbonates, sulfates, halite, and clay minerals, leaching, and cation exchanges, with the impact of evaporation and groundwater recharge of the aquifer. Moreover, the study of hydrochemical ratios is useful to delineate the groundwater origin depending on the genetic origin either meteoric or marine water, chloride ion for example is used to investigate the geochemical behavior for the major ions. Chloride is the most dissolved ion and less influenced by physical and chemical changes in water [21]. If the indices are greater than one then the water is of meteoric origin and the reverse refer to marine origin ,by applying the ratio of the major ions to chloride $[18,11]$.

The Dammam unconfined aquifer, Umaid Area - Muthanna Governorate - Iraq was selected to be the area of study due to its importance as the only groundwater source for agriculture. The Umaid area is located between latitudes ( $\left.31^{\circ} 19^{\prime} 22^{\prime \prime}-30^{\circ} 59^{\prime} 43^{\prime \prime}\right)$ North and longitudes (45 $\left.14^{\prime} 11^{\prime \prime}-45^{\circ} 2^{\prime} 40^{\prime \prime}\right)$ East (Fig. 1).The stratigraphy of the Umaid area composed of Dammam, Euphrates, and Rus Formations as well as the quaternary deposits. The groundwater is stored within the Dammam aquifer which underlies by Rus Formation. The Dammam Formation is composed of shallow neritic carbonates (limestone and dolomite) of middle to upper Eocene, and overlies by the Euphrates Formation (lower Miocene) of shallow marine carbonates with bedded marly limestone. Rus formation, (lower Eocene age) composed of anhydrite, thick bedded (about $35 \mathrm{~m}$.), subsidiary limestone with the existence of shale and marls. The recent deposits (thin sand sheets and gypsiferouse soil) form a discontinuous layer over the geological formations, and they may add ions to the Dammam unconfined aquifer with the percolated recharge water through the faults system in the area [29].

Al-Ansari et al, 1990 delineated the most promising areas for groundwater utilization for agricultural purposes and estimated the number of wells necessary for such a purpose. While Al-Shamaa, 1993 determined the hydrogeological characteristics of aquifers using pumping tests data and design of a multi-layer mathematical model.

Al-Shamari, 2006 Studied the hydrogeological and hydrochemical characteristics of the aquifers while Al-Azawi, 2016 considered the Dammam formation as a water-bearing formation, which represents the main produced reservoir of water in the study area and classified as unconfined aquifer.

The aim of this study is to investigate the Groundwater quality, groundwater-rock interaction and identify the hydrogeochemical processes of the Dammam unconfined aquifer, Umaid Area - Muthanna Governorate - Iraq.

\section{MATERIALS AND METHODS}

Twenty groundwater samples were collected from the Dammam unconfined aquifer, Umaid Area - Muthanna Governorate during October 2016 (Fig. 1). Depth of groundwater wells ranges from 50 to $150 \mathrm{~m}$, according to Al-Shamari, 2006. The measurements were done using procedure of APHA, 1998. All samples were analyzed for major ions $\mathrm{K}+, \mathrm{Na}+, \mathrm{Ca}_{2}^{+}, \mathrm{Mg}^{2+}, \mathrm{CO}_{3}{ }^{2+}, \mathrm{HCO}_{3}^{-}, \mathrm{SO}_{4}{ }^{2-}$, and $\mathrm{Cl}-$. Sodium and potassium was analyzed using flame photometer. Calcium, 
magnesium, chloride, carbonate and bicarbonate were determined by titrimetric method. Sulfate was determined by using of spectrophotometer. The hydrogen number $(\mathrm{pH})$, electrical conductivity (EC), TDS, and temperature (T) were measured directly in the field by using, HANA (HI 9811). The analytical accuracy was calculated according to Hem, 1985, accordingly, accuracy of results is accepted. Hydrochemical formula was computed as average formula based on Kurlolov formula which was referred in Ivanov et al., [18].

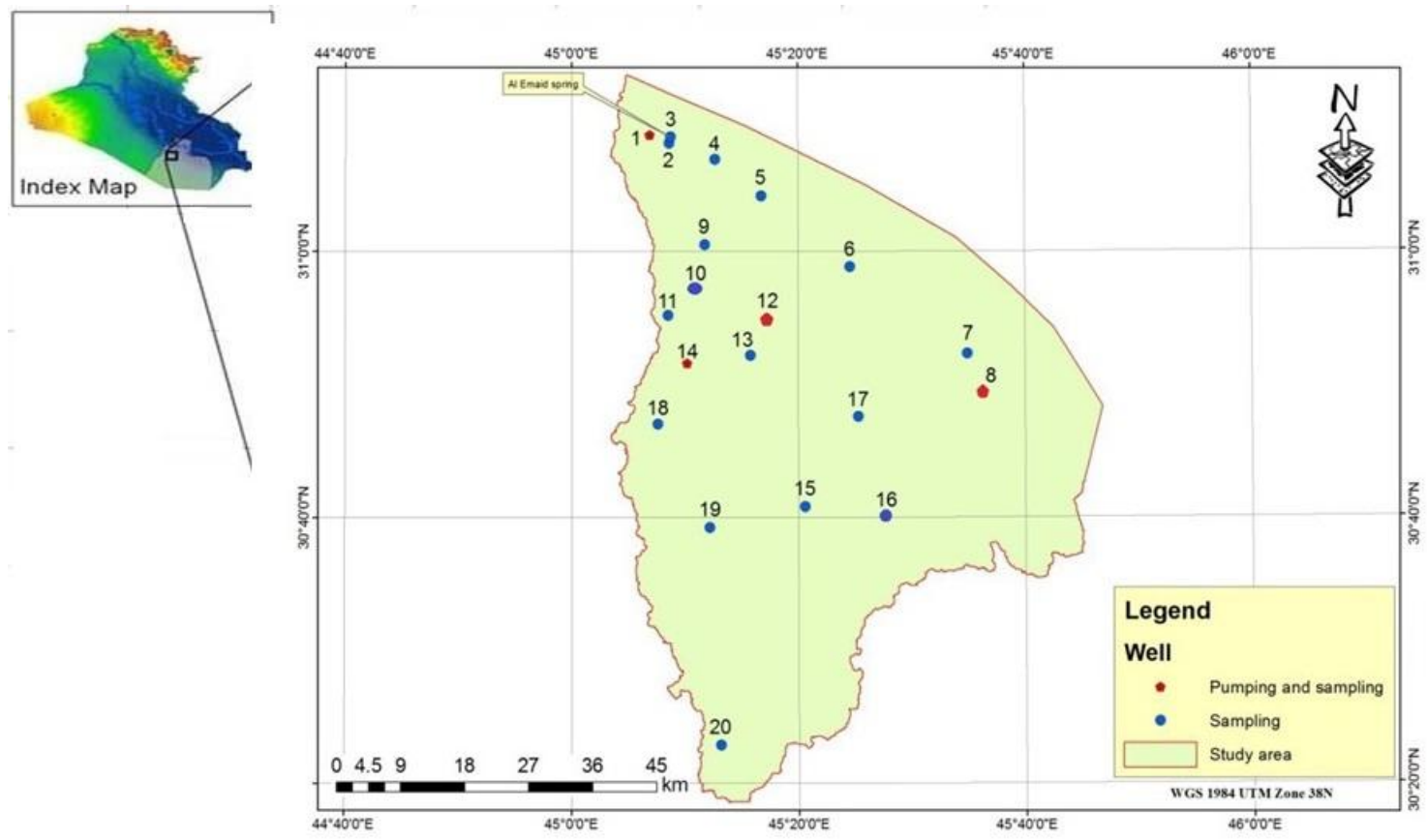

Fig. 1: the location of the study area and the groundwater wells in the Dammam unconfined aquifer, Umaid Area - Muthanna Governorate (After Sissakian, et al., 2000).

\section{RESULTS AND DISCUSSION}

\subsection{Groundwater characterization:}

The results reflect that the groundwater is classified as a neutral to slightly alkaline, where the $\mathrm{pH}$ values ranges from 7.3 to 7.8 according to Matthess [22] (Table 1). Wide range of variation was found in EC and TDS. The EC is ranging from 4520 to $6650 \mu \mathrm{s} / \mathrm{cm}$ reflecting excessively mineralized water [9], while the TDS varies from 2850 to $4330 \mathrm{ppm}$ indicating a slightly brackish water [30]. In addition, according to the results, the groundwater is classified as very hard water due to wide exposures of limestone in the recharge area according to Todd [30]. The dominant cation is Ca with average of $19 \%$, while the dominant anion is $\mathrm{SO}_{4}{ }^{2}$ with average of $27 \%$ from the total ions (Fig. 2)(Table 1). The ionic constituents of the groundwater in the Dammam unconfined aquifer are displayed by Stiff diagram of each studied well within the exposed geological formations (Fig. 3) [27]. The source of sulfate is believed to be from dissolving gypsum of Rus Formation, gypsiferous soil and to the partial mixing of water coming from multi-aquifer through the horizontal and vertical groundwater movement within the fault system in the area (Fig. 4). The Dammam aquifer in the study area is characterized by Ca-SO4 water type represented by the following hydrochemical formula:(Table 1).

\section{6 \\ $\mathrm{SO} 4(54.2) \mathrm{Cl}(36.8)$ \\ $\overline{\mathrm{Ca}(37.8) \mathrm{Na}(36.2) \mathrm{Mg}(23.1))} 7.5$}

An earth alkai waters rich by $\mathrm{Ca}^{2+}$ and $\mathrm{Mg}^{2+}$ with increase alkalis and prevailing sulfate and chloride can be described by Piper diagram that displays of about $90 \%$ groundwater samples, but the remnant $10 \%$ represents an alkali water rich by $\mathrm{Na}$ with prevailing sulfates and chloride (Figure 5 ). The ratio $\mathrm{rNa} / \mathrm{rCl} \geq 1$ reflects the dilution in groundwater due to the difference between the recharge processes of meteoric water and the artesian pressure of the deep wells. The access sodium obviously supports the marine origin from deep source that have been mixed with meteoric water is the source of the Dammam aquifer.

Table 1: The Hydrochemical parameters of groundwater in the Dammam unconfined aquifer, Umaid Area - Muthanna Governorate

\begin{tabular}{|c|c|c|c|c|c|c|c|c|c|c|}
\hline $\begin{array}{l}\text { Well } \\
\text { No }\end{array}$ & $\begin{array}{l}\mathrm{Na}^{+} \\
\text {epm }(\%)\end{array}$ & $\begin{array}{l}\mathrm{K}^{+} \\
\mathrm{epm} \%\end{array}$ & $\begin{array}{l}\mathrm{Mg}^{2+} \\
\mathrm{epm}(\%)\end{array}$ & $\begin{array}{l}\mathrm{Ca}^{2+} \\
\mathrm{epm}(\%)\end{array}$ & $\begin{array}{l}\mathrm{Cl}^{-} \\
\text {epm }(\%)\end{array}$ & $\begin{array}{l}\mathrm{SO}_{4}^{2-} \\
\text { epm }(\%)\end{array}$ & $\begin{array}{l}\mathrm{HCO}_{3}^{-} \\
\text {epm }(\%)\end{array}$ & $\begin{array}{l}\text { TDS } \\
\text { ppm }\end{array}$ & $\begin{array}{l}\text { EC } \\
\mu \mathrm{s} / \mathrm{cm}\end{array}$ & $\mathrm{pH}$ \\
\hline 1 & 42.6 & 4.4 & 23.9 & 29.1 & 35.4 & 54.7 & 9.9 & 3700 & 5800 & 7.4 \\
\hline 2 & 51.3 & 2.3 & 18.6 & 27.8 & 47.2 & 42.7 & 10.2 & 3530 & 5350 & 7.6 \\
\hline 3 & 51.9 & 0.5 & 19.2 & 28.4 & 46.6 & 41.9 & 11.5 & 3675 & 5520 & 7.5 \\
\hline 4 & 38.9 & 4.4 & 21.4 & 35.3 & 29.6 & 59.9 & 10.5 & 3965 & 5730 & 7.5 \\
\hline 5 & 34.5 & 3.8 & 26.0 & 35.8 & 30.4 & 57.2 & 12.3 & 4200 & 6040 & 7.6 \\
\hline 6 & 39.0 & 4.0 & 21.9 & 35.0 & 33.9 & 52.4 & 13.6 & 3950 & 6160 & 7.3 \\
\hline 7 & 38.5 & 4.5 & 21.6 & 35.4 & 32.6 & 57.0 & 10.4 & 4108 & 6100 & 7.5 \\
\hline 8 & 34.0 & 7.2 & 20.4 & 38.4 & 36.4 & 55.7 & 7.9 & 4330 & 6650 & 7.5 \\
\hline 9 & 30.9 & 1.0 & 21.4 & 46.7 & 34.4 & 62.5 & 3.1 & 3559 & 5664 & 7.3 \\
\hline 10 & 34.4 & 4.6 & 22.5 & 38.6 & 41.8 & 49.5 & 8.6 & 3180 & 5080 & 7.6 \\
\hline 11 & 30.4 & 4.8 & 26.5 & 38.3 & 40.8 & 50.5 & 8.6 & 3850 & 5620 & 7.8 \\
\hline 12 & 36.8 & 0.7 & 22.7 & 39.8 & 44.5 & 47.5 & 8.0 & 2850 & 4520 & 7.5 \\
\hline 13 & 36.3 & 0.8 & 23.4 & 39.5 & 43.7 & 46.6 & 9.7 & 2913 & 4730 & 7.3 \\
\hline 14 & 30.5 & 4.9 & 26.5 & 38.2 & 42.6 & 49.2 & 8.1 & 3950 & 5600 & 7.5 \\
\hline 15 & 34.2 & 0.7 & 22.0 & 43.0 & 30.3 & 60.0 & 9.6 & 3500 & 4950 & 7.6 \\
\hline 16 & 35.6 & 3.3 & 21.3 & 39.8 & 33.9 & 54.5 & 11.6 & 3940 & 5920 & 7.3 \\
\hline 17 & 35.8 & 2.2 & 21.6 & 40.3 & 32.6 & 56.8 & 10.6 & 3760 & 5600 & 7.6 \\
\hline
\end{tabular}


Citation: Moutaz A.Al-Dabbas, Yas K. Al-Ameri and Weam H. Kadhim, 2018. Groundwater Quality Investigation of the Dammam Unconfined Aquifer, Umaid Area - Muthanna Governorate - Iraq. Advances in Natural and Applied Sciences., 12(5): 24-34.

\begin{tabular}{|l|l|l|l|l|l|l|l|l|l|l|}
\hline 18 & 29.2 & 1.2 & 24.8 & 44.8 & 32.3 & 65.2 & 2.5 & 3414 & 5401 \\
\hline 19 & 27.2 & 1.1 & 31.5 & 40.2 & 31.0 & 65.4 & 3.6 & 3172 & 5005 & 7.3 \\
\hline 20 & 32.7 & 1.5 & 23.8 & 41.9 & 36.4 & 55.8 & 7.8 & 3570 & 5190 & 7.7 \\
\hline Average & 36.2 & 2.9 & 23.1 & 37.8 & 36.8 & 54.2 & 8.9 & 3656 & 5531.5 & 7.5 \\
\hline Min. & 27.2 & 0.5 & 18.6 & 27.8 & 29.6 & 41.9 & 2.5 & 2850.0 & 4520.0 & 7.3 \\
\hline Max. & 51.9 & 7.2 & 31.5 & 46.7 & 47.2 & 65.4 & 13.6 & 4330.0 & 6650.0 & 7.8 \\
\hline
\end{tabular}

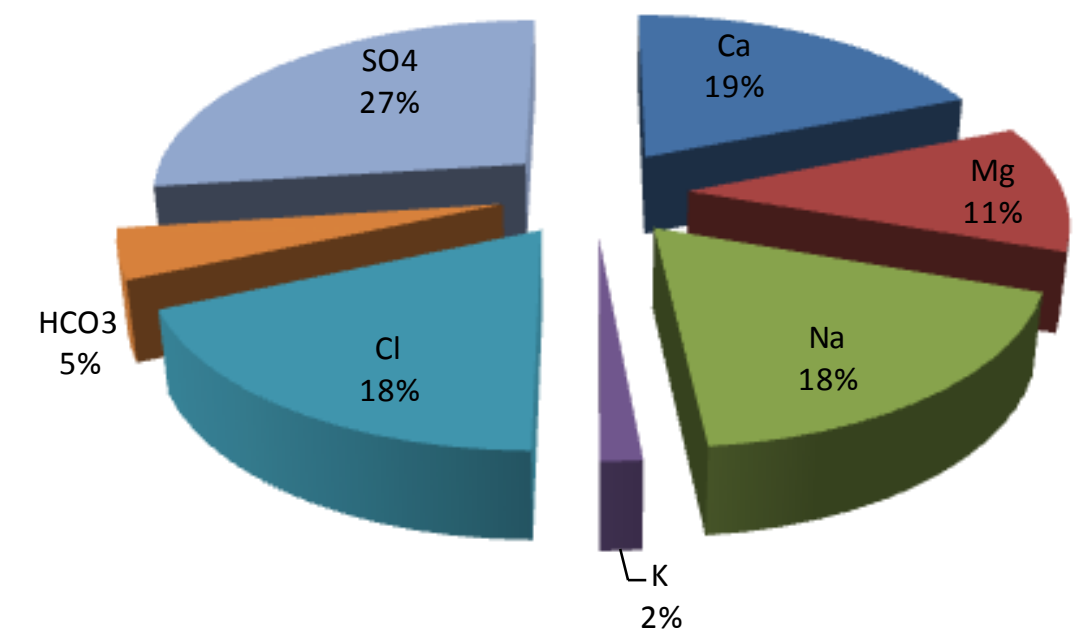

Fig. 2: Pie diagram displays the average ionic constituents of groundwater in the Dammam unconfined aquifer, Umaid Area - Muthanna Governorate.

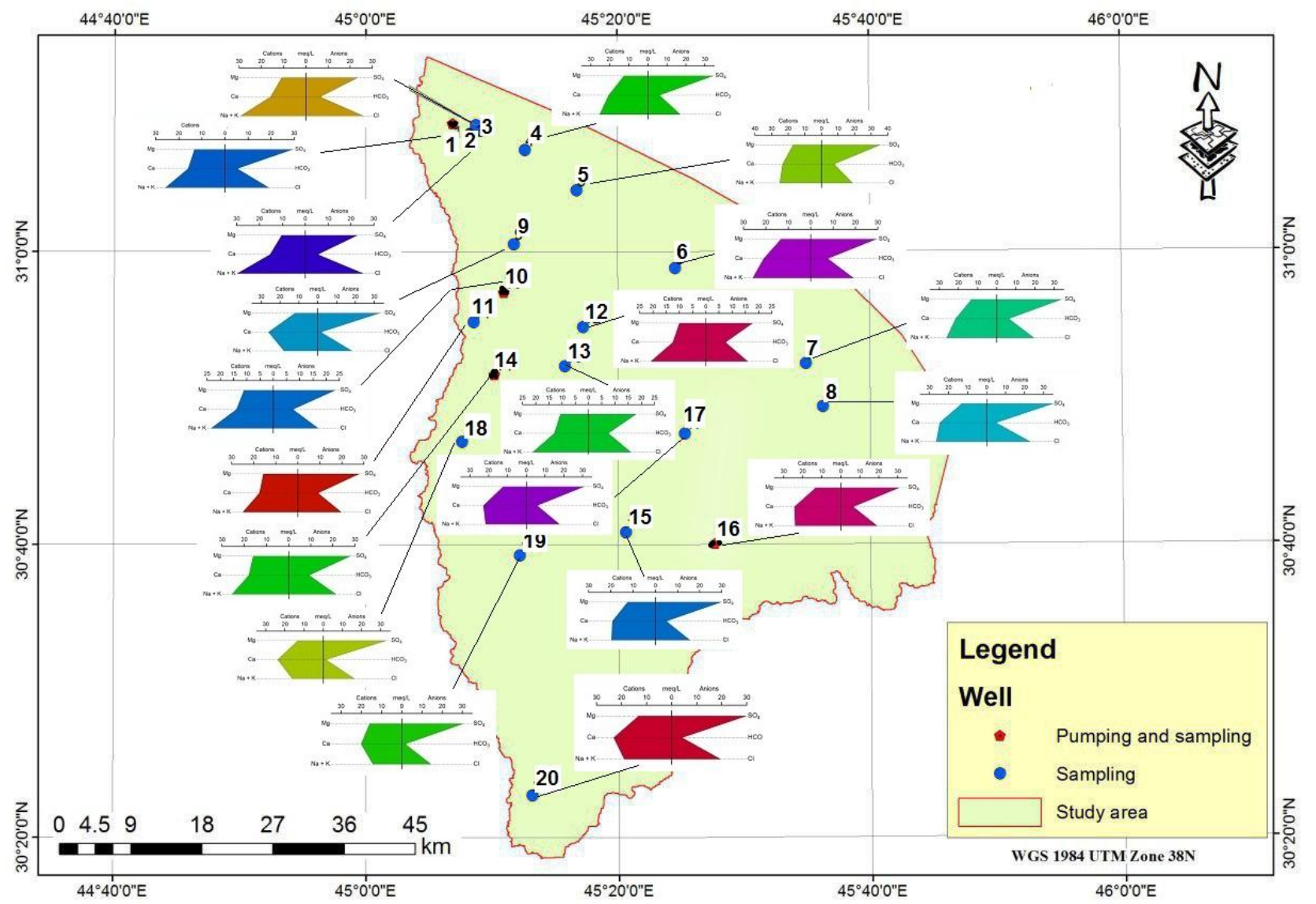

Fig. 3: Stiff diagram illustrates the chemistry of groundwater in the Dammam unconfined aquifer, Umaid Area - Muthanna Governorate and studied groundwater wells [27] 


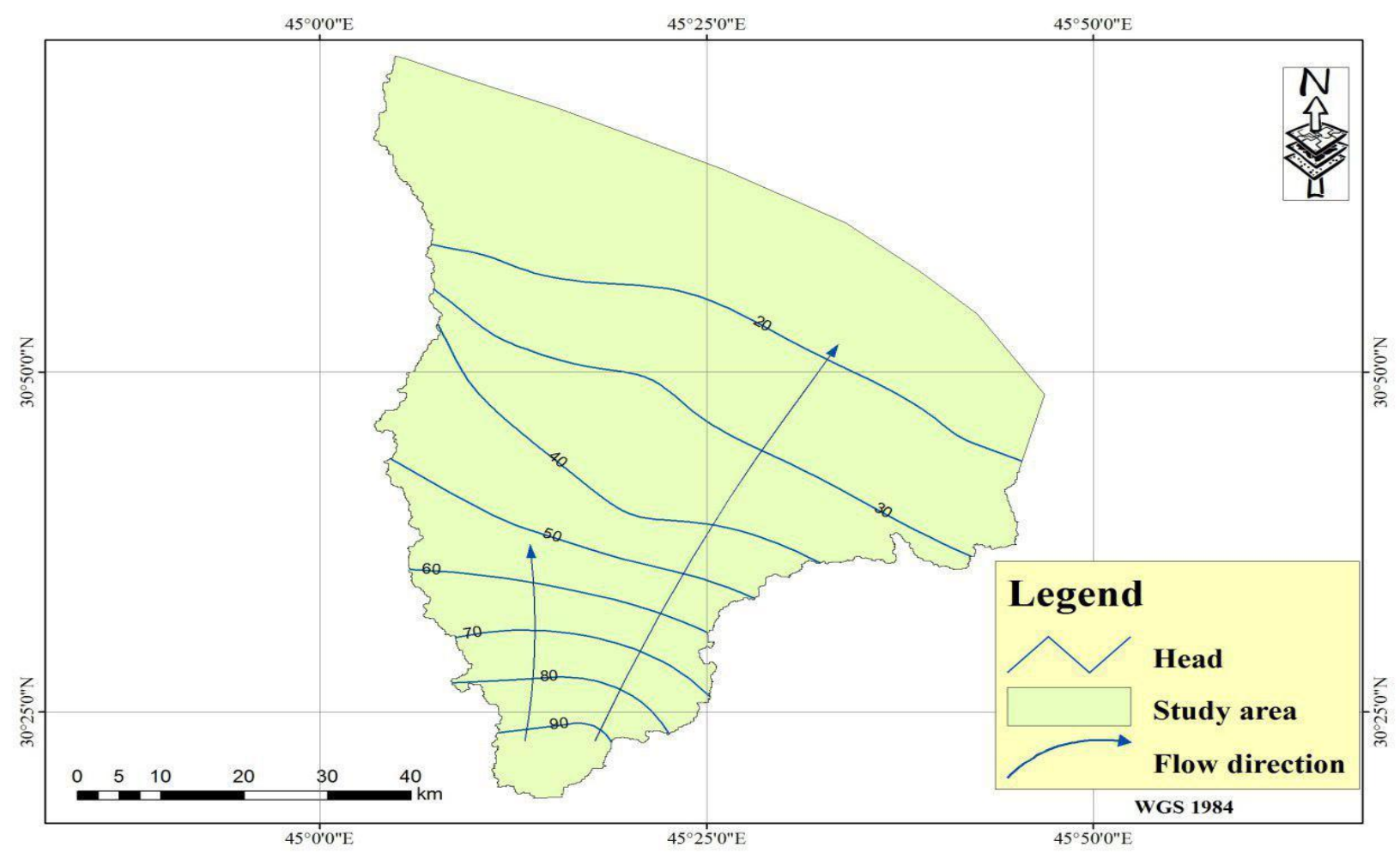

Fig. 4: Groundwater flow movement of the Dammam unconfined aquifer, Umaid Area - Muthanna Governorate [16].

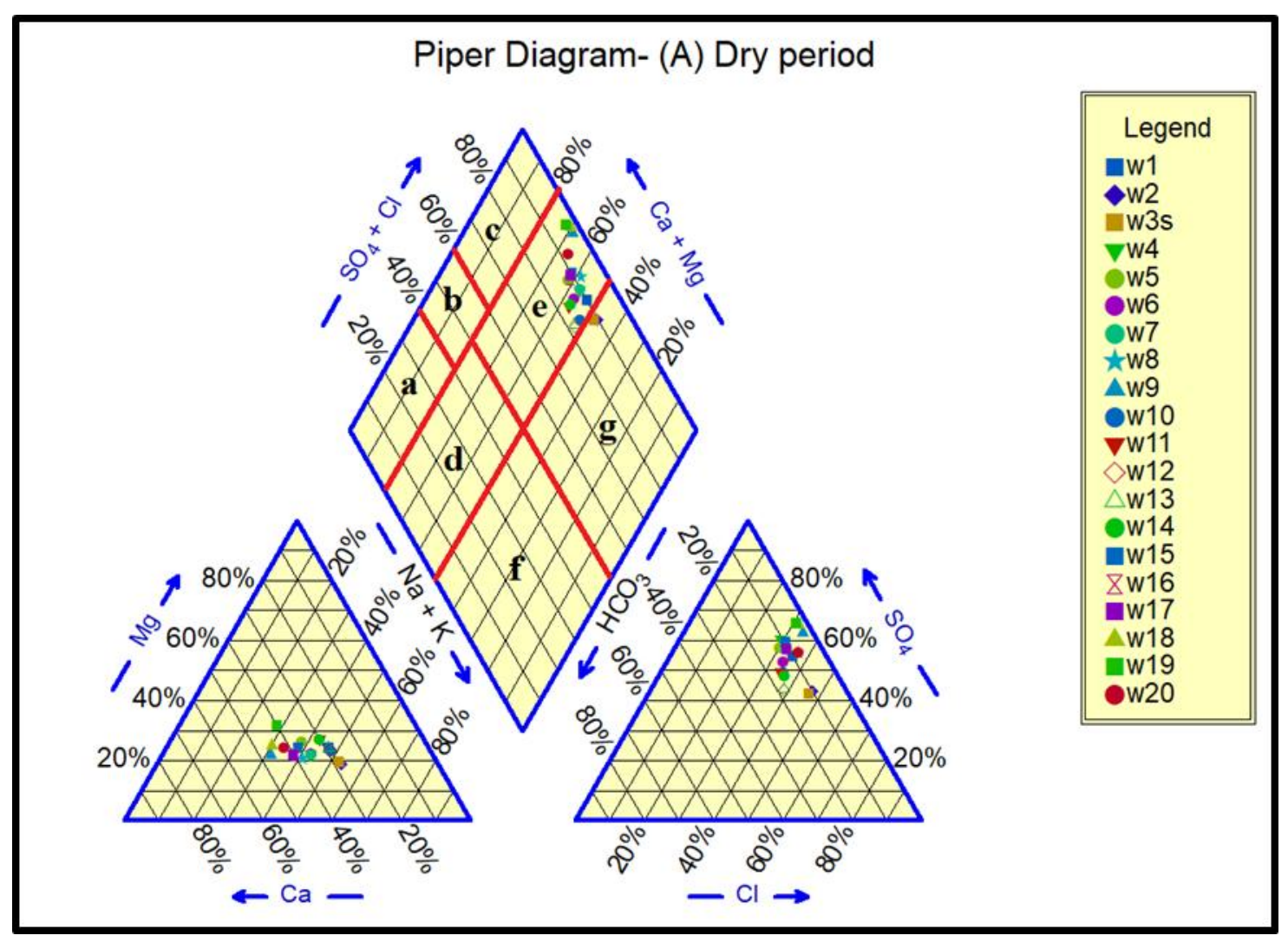

Fig. 5: Piper diagram display groundwater facies in the Dammam unconfined aquifer, Umaid Area - Muthanna Governorate [25].

\subsection{Groundwater - rock interaction:}

The hydrochemical functions may reflect the aquifer characterization by concluding the rock-water interaction [28]. The results indicate the ratio of $\mathrm{rCa}^{2+} / \mathrm{rMg}^{2+}$ with the average value (1.65) is between of seawater $(0.14)$ and rainwater (7.14) [10]. Such finding reflects the interaction between recharge water and rocks of the aquifer causing dissolution of carbonates (limestone and dolomite) under acidic $\mathrm{pH}$ conditions ( $\mathrm{pH}$ of recharge water). While the ratio $\mathrm{rNa}+\mathrm{rCl}-\mathrm{show}$ the $\mathrm{Na}^{+}$concentration is high relative to the $\mathrm{Cl}^{-}$value that represented by the average value (1.1). This finding indicates a presence of another source of $\mathrm{Na}$ rather than halite that provides an evidence of dissolution of terrestrial minerals during partial leaching (Table 2). The dissolution of the gypsum and anhydrite in the 
Citation: Moutaz A.Al-Dabbas, Yas K. Al-Ameri and Weam H. Kadhim, 2018. Groundwater Quality Investigation of the Dammam Unconfined Aquifer, Umaid Area - Muthanna Governorate - Iraq. Advances in Natural and Applied Sciences., 12(5): 24-34.

aquifer are indicated by $\mathrm{rSO}_{4}{ }^{2-} / \mathrm{rCl}^{-}$ratio with the high average value (1.53) in groundwater samples, while it is 0.10 in seawater (Collins, 1975).Such result is in accordance with Jamil, 1977, finding that the $\mathrm{rSO}_{4}{ }^{2}$-/rCl- ratio is 2.1 in Damman unconfined aquifer water.

Table 2: Hydrochemical function (epm) of groundwater in the Dammam unconfined aquifer, Umaid Area - Muthanna Governorate.

\begin{tabular}{|c|c|c|c|c|c|c|c|c|c|c|}
\hline S.No. & $\mathrm{Ca} / \mathrm{Mg}$ & $\mathrm{SO}_{4}^{\prime} \mathrm{Cl}$ & $\mathrm{Ca}+\mathrm{Mg}$ & $\mathrm{SO}_{4}+\mathrm{HCO}_{3}$ & $\mathrm{Cl}$ & $\mathrm{Na}+\mathrm{K}$ & $\mathrm{Na} / \mathrm{Cl}$ & $\mathrm{Na}$ & $\begin{array}{l}\mathrm{Cl} /(\mathrm{Cl} \\
\left.+\mathrm{HCO}_{3}\right)\end{array}$ & $\begin{array}{l}\mathrm{Na} /(\mathrm{Na} \\
+\mathrm{Ca})\end{array}$ \\
\hline 1 & 1.22 & 1.54 & 29.2 & 34.7 & 19.0 & 25.9 & 1.23 & 23.5 & 0.78 & 0.59 \\
\hline 2 & 1.50 & 0.90 & 25.8 & 28.4 & 25.4 & 29.8 & 1.12 & 28.5 & 0.82 & 0.65 \\
\hline 3 & 1.48 & 0.90 & 26.8 & 29.7 & 25.9 & 29.4 & 1.13 & 29.2 & 0.80 & 0.65 \\
\hline 4 & 1.65 & 2.02 & 33.2 & 40.5 & 17.0 & 25.4 & 1.34 & 22.8 & 0.74 & 0.52 \\
\hline 5 & 1.38 & 1.88 & 40.5 & 43.0 & 18.8 & 25.1 & 1.20 & 22.6 & 0.71 & 0.49 \\
\hline 6 & 1.60 & 1.54 & 34.2 & 37.0 & 19.0 & 25.9 & 1.23 & 23.5 & 0.71 & 0.53 \\
\hline 7 & 1.64 & 1.75 & 34.8 & 40.0 & 19.4 & 26.3 & 1.21 & 23.5 & 0.76 & 0.52 \\
\hline 8 & 1.89 & 1.53 & 37.9 & 39.9 & 22.8 & 26.5 & 0.96 & 21.9 & 0.82 & 0.47 \\
\hline 9 & 2.18 & 1.82 & 38.3 & 34.7 & 18.2 & 17.9 & 0.96 & 17.4 & 0.92 & 0.40 \\
\hline 10 & 1.72 & 1.18 & 30.1 & 27.6 & 19.8 & 19.2 & 0.86 & 17.0 & 0.83 & 0.47 \\
\hline 11 & 1.44 & 1.24 & 38.1 & 32.6 & 22.5 & 20.7 & 0.79 & 17.9 & 0.83 & 0.44 \\
\hline 12 & 1.75 & 1.07 & 27.5 & 23.3 & 18.7 & 16.5 & 0.87 & 16.2 & 0.85 & 0.48 \\
\hline 13 & 1.69 & 1.07 & 28.7 & 24.3 & 18.9 & 16.9 & 0.88 & 16.5 & 0.82 & 0.48 \\
\hline 14 & 1.44 & 1.15 & 39.0 & 32.6 & 24.2 & 21.3 & 0.76 & 18.3 & 0.84 & 0.44 \\
\hline 15 & 1.95 & 1.98 & 36.8 & 35.8 & 15.6 & 19.8 & 1.24 & 19.3 & 0.76 & 0.44 \\
\hline 16 & 1.87 & 1.61 & 37.6 & 37.4 & 19.2 & 24.0 & 1.15 & 22.0 & 0.74 & 0.47 \\
\hline 17 & 1.87 & 1.74 & 35.3 & 36.8 & 17.7 & 21.7 & 1.15 & 20.4 & 0.75 & 0.47 \\
\hline 18 & 1.81 & 2.02 & 37.3 & 34.1 & 16.3 & 16.3 & 0.96 & 15.7 & 0.93 & 0.39 \\
\hline 19 & 1.28 & 2.11 & 36.0 & 32.3 & 14.5 & 14.3 & 0.94 & 13.7 & 0.90 & 0.40 \\
\hline 20 & 1.76 & 1.53 & 36.4 & 34.0 & 19.5 & 19.0 & 0.93 & 18.1 & 0.82 & 0.44 \\
\hline Av. & 1.65 & 1.53 & 34.18 & 33.0 & 19.6 & 22.1 & 1.1 & 20.4 & 0.81 & 0.49 \\
\hline $\begin{array}{l}\text { Sea water } \\
\text { Collins, } 1975\end{array}$ & & 0.10 & & & & & 0.85 & & & \\
\hline Jamil,1977 & & 2.1 & & & & & 1.1 & & & \\
\hline
\end{tabular}

The graphic relation of $\mathrm{Ca}^{2+}+\mathrm{Mg}^{2+}$ versus $\mathrm{SO}_{4}{ }^{2-}+\mathrm{HCO}_{3}{ }^{-}$is being close to the 1:1 line as normal case if the dissolutions of calcite, dolomite and gypsum are the dominant reactions in the aquifer $[6,12]$.

The points will be shifted to the left due to a large excess of calcium and magnesium relative to sulfates and bicarbonates. The reverse is true, when the Ion exchange tends to shift points to the right due to an excess of $\mathrm{SO}_{4}{ }^{2-}+\mathrm{HCO}_{3}{ }^{-}$. The groundwater samples of the Dammam unconfined aquifer, Umaid area are shifted relatively to the left as resulted of calcium and magnesium excess relative to sulfates and bicarbonates (Figure 5).
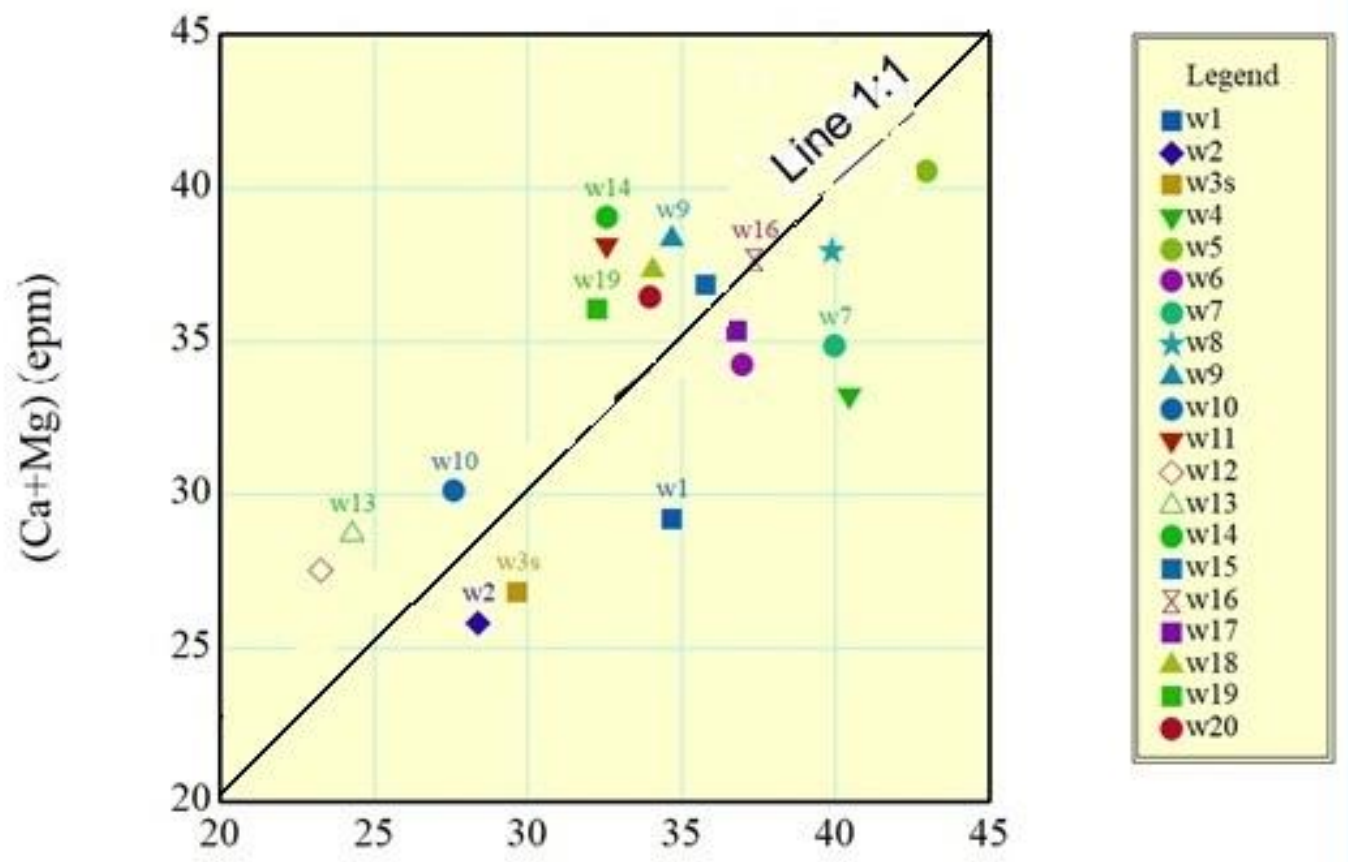

$(\mathrm{SO} 4+\mathrm{HCO} 3)(\mathrm{epm})$

Fig. 5: Relation between $\mathrm{Ca}^{2+}+\mathrm{Mg}^{2+}$ and $\mathrm{SO}_{4}{ }^{2-}+\mathrm{HCO}_{3}{ }^{-}$in groundwater of the Dammam unconfined aquifer, Umaid area - Muthanna Governorate.

The $\mathrm{Ca} / \mathrm{Mg}$ ratio equal 1.0 indicates dissolution of dolomite, but a higher ratio reflects a greater calcite contribution according to Maya and Loucks, 1995 conclusion. The very high $\mathrm{Ca}^{2+}+\mathrm{Mg}^{2+}$ molar values (more than 25.0 to $40.5 \mathrm{epm}$ ) indicate the contribution of $\mathrm{Ca}^{2+}$ and $\mathrm{Mg}^{2+}$ to groundwater due to dissolution of calcite, dolomite and gypsum (Figure 6). 


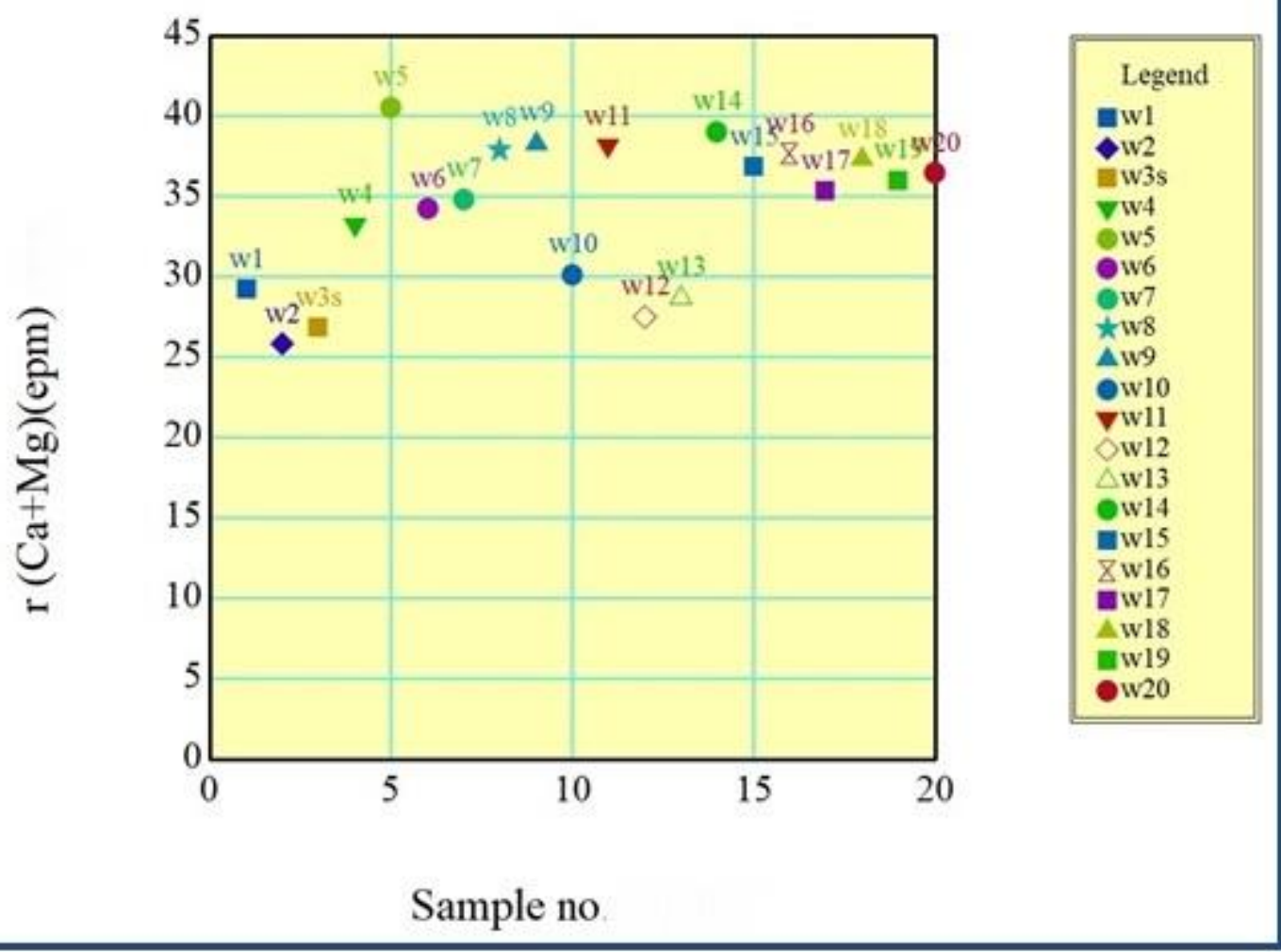

Fig. 6: The scatter diagram of $\mathrm{Ca}^{2+}+\mathrm{Mg}^{2+}(\mathrm{epm})$ in groundwater samples of the Dammam unconfined aquifer, Umaid Area - Muthanna Governorate.

As well as the increase of both calcium and magnesium ions are indicating the effect of salinity and the weathering of carbonate rocks in the aquifer that was done by chloride-bearing water (Figure 7). The major sources of $\mathrm{Ca}^{2+}$ are limestone, dolomite, dolomitic limestone, marl and gypsum, whereas the $\mathrm{Mg}^{2+}$ sources are dolomitic limestone and dolomite. Carbonates of the Euphrates and Dammam Formations and gypsum of the Rus Formation have been subjected to dissolution, then added $\mathrm{Ca}^{2+}, \mathrm{Mg}^{2+}, \mathrm{CO}_{3}{ }^{2-}$ and $\mathrm{SO}_{4}{ }^{2-}$ to the groundwater system as recharged water during rainfall, leaching during irrigation as well as the groundwater movement in the aquifer.

The distribution pattern of the $\mathrm{Na}^{+}+\mathrm{K}^{+} \geq 0.33$ are plotted along total cations of the groundwater samples, that give better understanding of Clay minerals weathering (Figure 8) [10]. It clearly reflects the halite dissolution because $\mathrm{Na}^{+}$contributes by average of $36.2 \mathrm{epm} \%$ and $\mathrm{K}^{+}$contributes by only 2.9 epm $\%$ average from the total anions.

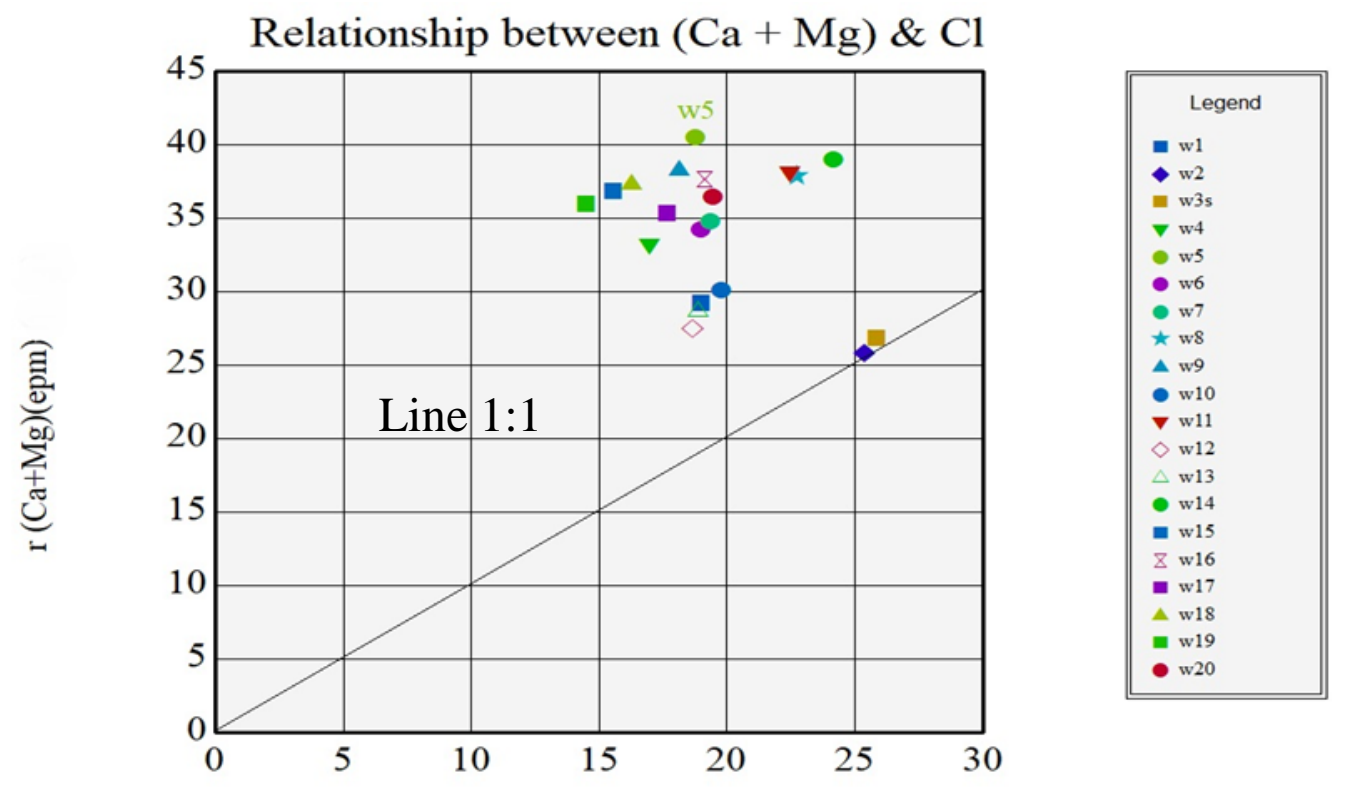

Chloride (epm)

Fig. 7: Relationship between $(\mathrm{Ca}+\mathrm{Mg})$ and $\mathrm{Cl}$ in groundwater of the Dammam unconfined aquifer, Umaid Area - Muthanna Governorate. 


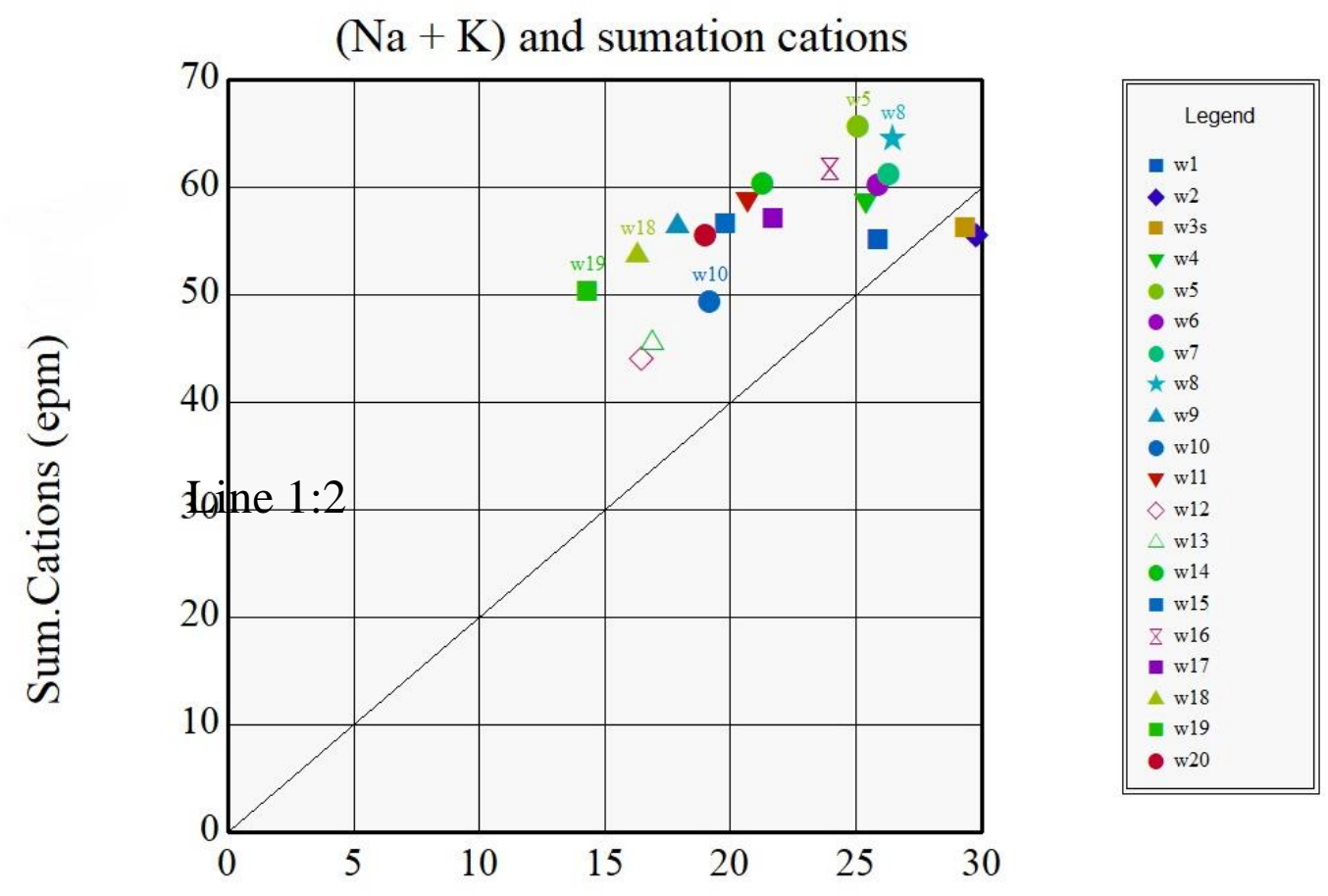

\section{$\mathrm{Na}+\mathrm{K}(\mathrm{epm})$}

Fig. 8: Relationship between $(\mathrm{Na}+\mathrm{K})$ and total cations (epm).

\subsection{Groundwater chemistry control:}

$\mathrm{The} \mathrm{Na/Clmolar}$ ratio can be used to identify the evaporation process in ground water as well as if it is more than one reflects the continental origin of the groundwater [28]. The molar ratio of $\mathrm{Na} / \mathrm{Cl}$ against $\mathrm{EC}$ plot was used to understand the dominant chemical processes in the Dammam unconfined aquifer, Umaid Area - Muthanna Governorate. A horizontal line resulted from the plot of $\mathrm{Na} / \mathrm{Cl}$ against $\mathrm{EC}$ means concentration via evaporation [20]. The molar ratio of $\mathrm{Na} / \mathrm{Cl}$ still constant and approximately close to 1.0 in case of halite dissolution, but the greater than 1.0 means that Na released may be from silicate weathering [24].

Based on this ratio, 10 groundwater samples out of 20 samples are greater than 1.0, the average of all the samples is 1.1ranging from 0.76 to 1.34 (Table 2 and Figure 9).This means a presence of other processes beside halite dissolution that might be existed; it would be clay minerals (silicate) dissolution. The distribution pattern of the molar ratio of $\mathrm{Na} / \mathrm{Cl}$ versus electrical conductivity displays a special trend may reflect the minimum effect of evaporation on chemistry of groundwater in the Dammam unconfined aquifer. Groundwater has unique chemistry due to several processes like lithology-water interaction during recharge and groundwater flow, prolonged storage in the aquifer, dissolution of mineral species [14].

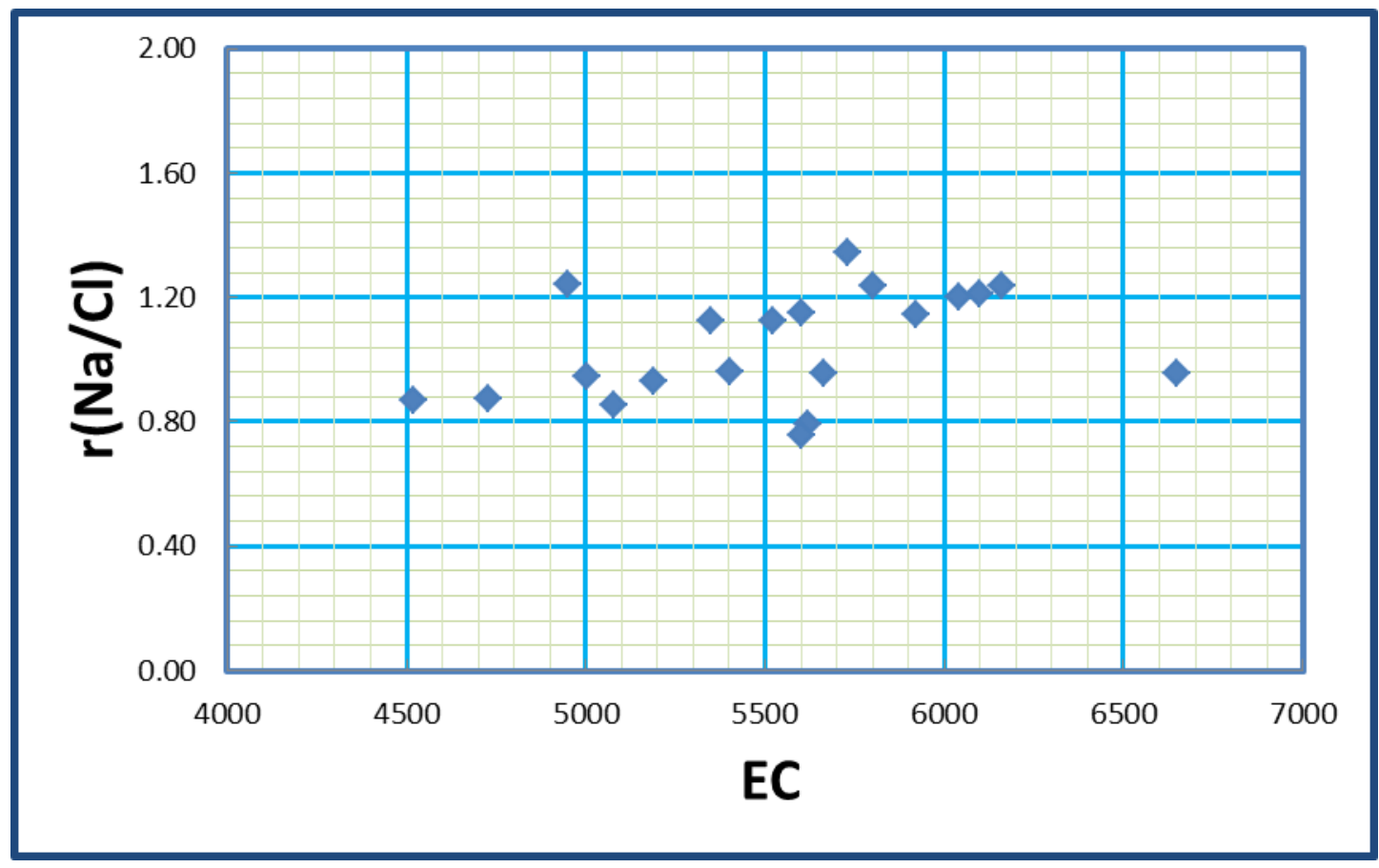

Fig. 9: Distribution pattern of $(\mathrm{Na} / \mathrm{Cl})$ against $\mathrm{EC}$ in groundwater of the Dammam unconfined aquifer, Umaid Area - Muthanna Governorate. 
The relationship between $\mathrm{Na}+$ and $\mathrm{Cl}^{-}$reflects about $50 \%$ of groundwater samples fell below the 1:1 line which may be attributed to the ionic exchange in clay minerals and silicate weathering as additional source of $\mathrm{Na}^{+}$rather than halite dissolution (Figure 10).

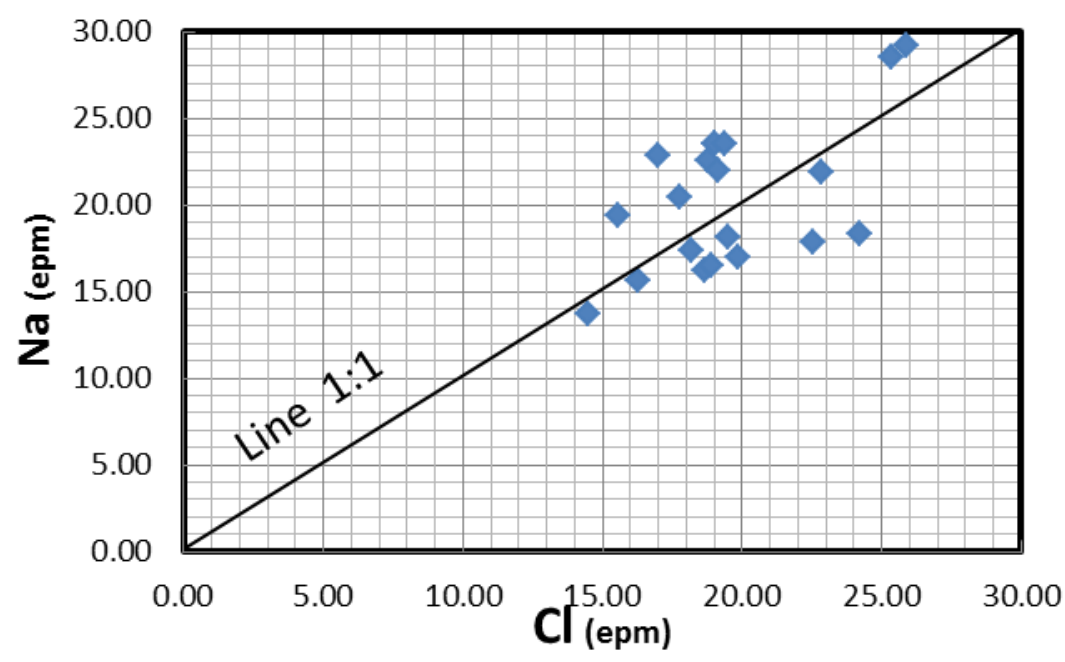

Fig. 10: relationship between the molar ration of $\mathrm{Na}$ and $\mathrm{Cl}$ of the Dammam unconfined aquifer, Umaid Area - Muthanna Governorate.

Applying Gibbs, 1970, diagram was to discriminate the evaporation, dilution and rock weathering as hydrochemical processes affected groundwater. The Gibbs diagram was mainly shared the chemical weathering and evaporation and it indicated that the groundwater chemistry was mainly controlled by weathering reactions (Figure 11A-B). Gibbs Diagram display that there is no dilution process which reflects the lack of the amount of annual precipitation in the recharge area that feed the Dammam unconfined aquifer, Umaid Area - Muthanna Governorate.

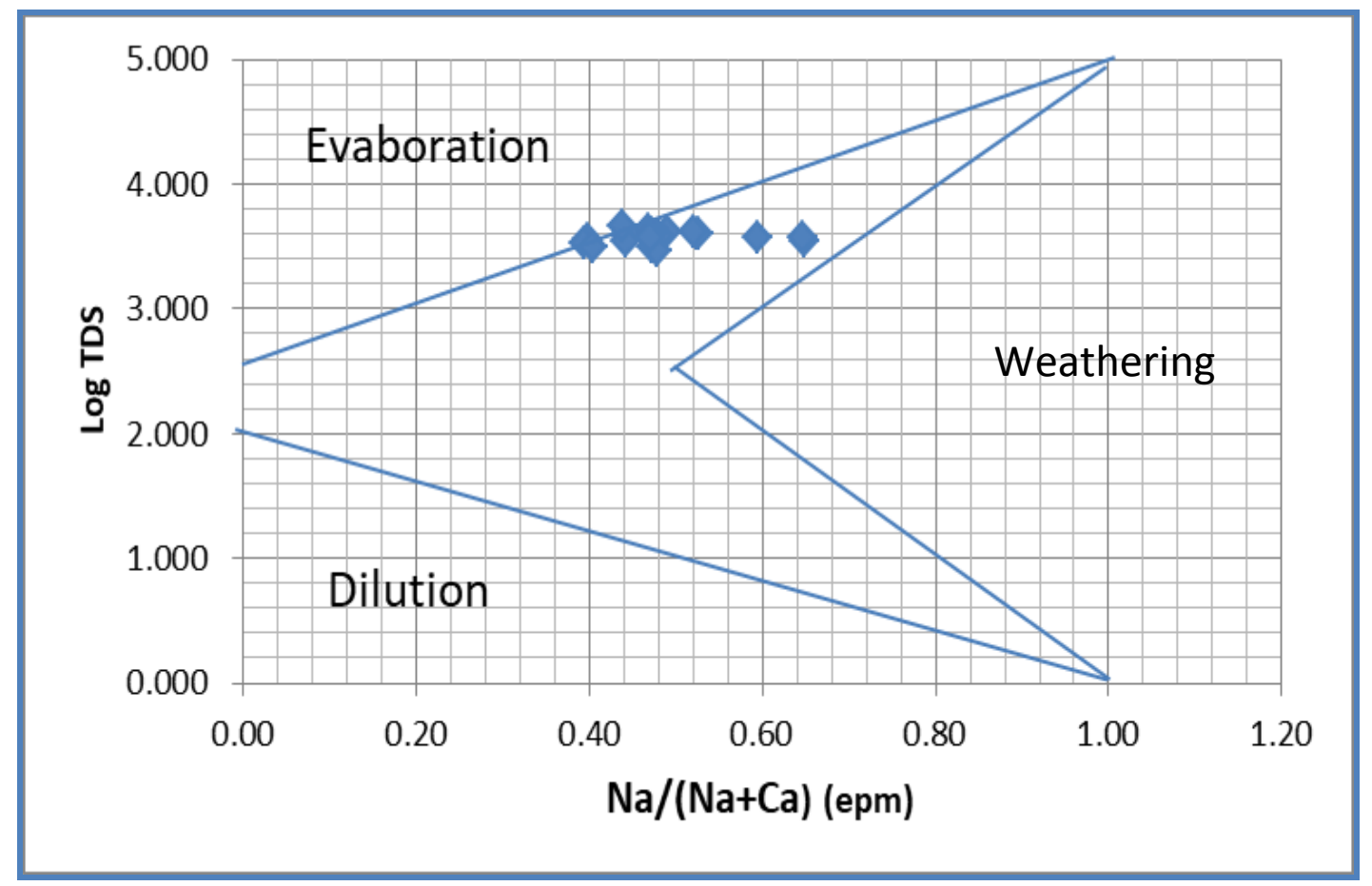




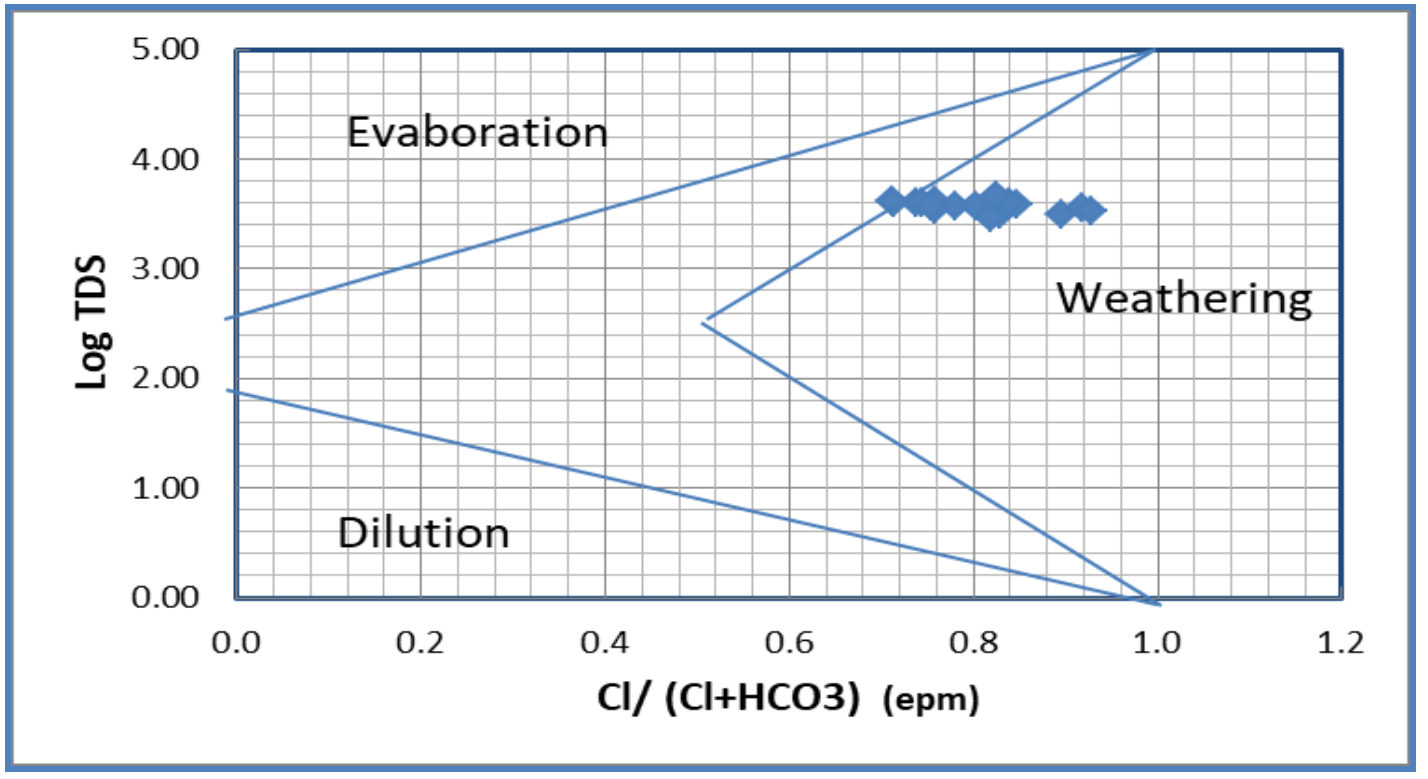

Fig. 11: A and B; Gibbs diagrams classification of groundwater samples of the Dammam unconfined aquifer, Umaid Area - Muthanna Governorate.

\subsection{Enrichments of Ions:}

The interpretation of the probable source rock was done following many sequential steps and based on the computed results given in Table 3 [15]. To describe source ions and rocks affected groundwater chemistry, the chemical functions are used as follows:

1. The values of the ratio of $\mathrm{Na} /(\mathrm{Na}+\mathrm{Cl})$ indicates that there is a possible contribution of the sea water in the Dammam unconfined aquifer, Umaid Area Muthanna Governorate in $40 \%$ wells, where the values of this ratio are more than 0.5 .

2. The values of the ratio of $\mathrm{Mg} /(\mathrm{Ca}+\mathrm{Mg})$ is less than 0.5 indicates limestone-dolomite weathering, but if it is greater than 0.5 indicates dolomite dissolution and calcite precipitation. The computed values of this function (less than 0.5 ) reflect the limestone-dolomite weathering as a dominant process.

3. If the calculated values of the ratio of $\mathrm{Ca} /\left(\mathrm{Ca}+\mathrm{SO}_{4}\right)$ are less 0.5 , it means calcium removal byion exchange or calcite precipitations. But if it is greater than 0.5 indicating calcium source such as gypsum, carbonate or silicates. In the present study, values of this function are less than 0.5 indicating Ca ${ }^{2+}$ removal by ion exchange or calcite precipitation. $\mathrm{pH}$ values don't support the $\mathrm{Ca}^{2+}$ precipitation in the Dammam unconfined aquifer, Umaid Area - Muthanna Governorate.

4. The values of the ratio of $\mathrm{Mg} /\left(\mathrm{Ca}+\mathrm{SO}_{4}\right)$ are less than of 0.5 in the Dammam unconfined aquifer, Umaid Area - Muthanna Governorate indicating contribution calcite and gypsum more than contribution of dolomite.

5. If the computed ratio of $(\mathrm{Ca}+\mathrm{Mg}) / \mathrm{SO}_{4}$ fall within 0.8-1.2 indicating dedolomitization. The result reflects that there is an effective dedolomitization process indicated by about $100 \%$ of the computed ratios of this function for the groundwater samples.

6. If the value of TDS greater than $500 \mathrm{ppm}$; it mostly indicates carbonate weathering or brine or seawater, if less than $500 \mathrm{ppm}$, it indicates silicate weathering. TDS data refer to the carbonate weathering as the values in the Dammam unconfined aquifer, Umaid Area - Muthanna Governorate is greater than $500 \mathrm{ppm}$.

7. If the values of the ratio of $\mathrm{Cl} / 5$ anions are less 0.8 indicating rock weathering. Consequently, the rock weathering was the dominant process in Dammam Aquifer, so as all the values of these ratios are less than 0.8 .

8. If the calculated value of the ratio of $\mathrm{HCO}_{3} / \sum$ anions is less than 0.8 , indicates seawater or brine. Accordingly, $40 \%$ computed data are less than 0.8 , then it indicates a brine water may affected by connate or fossils water that might be feeding along the faults system in the area. This can be attributed to the existence of a deep recharge from the deeper aquifers in these wells.

Table 3: Computed function for the source rock interpretation

\begin{tabular}{|c|c|c|c|c|c|c|c|c|c|c|}
\hline S.No & $\begin{array}{l}\mathrm{Na} / \\
(\mathrm{Na}+\mathrm{Cl})\end{array}$ & $\begin{array}{l}\mathrm{Mg} / \\
(\mathrm{Ca}+\mathrm{Mg})\end{array}$ & $\begin{array}{l}\mathrm{Ca} / \\
\left(\mathrm{Ca}+\mathrm{SO}_{4}\right)\end{array}$ & $\begin{array}{l}\mathrm{Mg} / \\
\left(\mathrm{Ca}+\mathrm{SO}_{4}\right)\end{array}$ & $\begin{array}{l}(\mathrm{Ca}+\mathrm{Mg}) / \\
\mathrm{SO}_{4}\end{array}$ & $\begin{array}{l}\mathrm{Na} /(\mathrm{Cl}+\mathrm{S} \\
\mathrm{O} 4)\end{array}$ & $\begin{array}{l}(\mathrm{Na}+\mathrm{Mg}) / \\
\mathrm{Cl}\end{array}$ & $\begin{array}{l}\mathrm{Cl} / \\
\text { KAnions }\end{array}$ & $\begin{array}{ll}\mathrm{HCO}_{3} & / \\
\sum \text { Anions }\end{array}$ & $\begin{array}{l}\text { TDS } \\
\text { ppm }\end{array}$ \\
\hline 1 & 0.55 & 0.45 & 0.35 & 0.29 & 1.00 & 1.93 & 0.49 & 0.35 & 0.10 & 3700 \\
\hline 2 & 0.53 & 0.40 & 0.40 & 0.27 & 1.12 & 1.53 & 0.59 & 0.47 & 0.10 & 3530 \\
\hline 3 & 0.53 & 0.40 & 0.41 & 0.28 & 1.15 & 1.54 & 0.59 & 0.47 & 0.11 & 3675 \\
\hline 4 & 0.57 & 0.38 & 0.38 & 0.23 & 0.97 & 2.08 & 0.44 & 0.30 & 0.11 & 3965 \\
\hline 5 & 0.55 & 0.42 & 0.40 & 0.29 & 1.15 & 2.11 & 0.42 & 0.30 & 0.12 & 4200 \\
\hline 6 & 0.55 & 0.39 & 0.42 & 0.26 & 1.17 & 1.93 & 0.49 & 0.34 & 0.14 & 3950 \\
\hline 7 & 0.55 & 0.38 & 0.39 & 0.24 & 1.03 & 1.89 & 0.44 & 0.33 & 0.10 & 4108 \\
\hline 8 & 0.49 & 0.35 & 0.41 & 0.22 & 1.08 & 1.53 & 0.38 & 0.36 & 0.08 & 4330 \\
\hline 9 & 0.49 & 0.31 & 0.44 & 0.20 & 1.16 & 1.62 & 0.34 & 0.34 & 0.03 & 3559 \\
\hline 10 & 0.46 & 0.37 & 0.45 & 0.26 & 1.28 & 1.41 & 0.39 & 0.42 & 0.09 & 3180 \\
\hline 11 & 0.44 & 0.41 & 0.45 & 0.31 & 1.36 & 1.48 & 0.35 & 0.41 & 0.09 & 3850 \\
\hline 12 & 0.46 & 0.36 & 0.47 & 0.27 & 1.38 & 1.40 & 0.42 & 0.45 & 0.08 & 2850 \\
\hline 13 & 0.47 & 0.37 & 0.47 & 0.28 & 1.43 & 1.44 & 0.42 & 0.44 & 0.10 & 2913 \\
\hline 14 & 0.43 & 0.41 & 0.45 & 0.31 & 1.39 & 1.42 & 0.35 & 0.43 & 0.08 & 3950 \\
\hline 15 & 0.55 & 0.34 & 0.44 & 0.23 & 1.19 & 2.04 & 0.42 & 0.30 & 0.10 & 3500 \\
\hline 16 & 0.53 & 0.35 & 0.44 & 0.24 & 1.22 & 1.83 & 0.44 & 0.34 & 0.12 & 3940 \\
\hline 17 & 0.54 & 0.35 & 0.43 & 0.23 & 1.14 & 1.84 & 0.42 & 0.33 & 0.11 & 3760 \\
\hline 18 & 0.49 & 0.36 & 0.42 & 0.23 & 1.14 & 1.78 & 0.32 & 0.32 & 0.03 & 3414 \\
\hline 19 & 0.49 & 0.44 & 0.40 & 0.31 & 1.18 & 2.03 & 0.30 & 0.31 & 0.04 & 3172 \\
\hline 20 & 0.48 & 0.36 & 0.44 & 0.25 & 1.22 & 1.61 & 0.37 & 0.36 & 0.08 & 3570 \\
\hline Aver. & 0.51 & 0.38 & 0.42 & 0.26 & 1.19 & 4.74 & 0.42 & 0.37 & 0.09 & 3656 \\
\hline
\end{tabular}


3.5 Evaluation of groundwater quality:

The groundwater suitability is necessary to assess the waters for different uses by compared with the permissible limits [17,31]. Accordingly, the subject of waters analyses interpretation must often include some consideration of standards and tolerances that have been established for water that is to be used for various purposes [14].

In general, the variation of the groundwater quality can be attributed to the lithological and mineralogical contents of the geological formation as well as to the spatial variation in controlling factors that are responsible for sedimentation and dissolution of different minerals. The existence of several economic projects (such as agricultural and industrial projects) were added more reasons for groundwater contamination. Moreover, some of the studied wells were located in area affected by human activity and domestic sewage effluent to the water sources, therefore unsatisfactory for drinking. Possible sources of contamination include leaking septic systems, runoff from agricultural lots or from decaying plant materials and soils.

The groundwater chemical analyses indicated that they are unsuitable for human drinking purposes according to IQS, [17] and WHO, [31], (Table 4). While, the groundwater of the study area is suitable to agricultural most of Fruit crops, most of vegetable and field crops according to Todd 2007 ,as well as all groundwater samples are weak and suitable for all livestock, and are not suitable for poultry according to Crist and Lowery, [8], classifications.

Table 4: Comparison of the groundwater samples with the Iraqi, 2001 and WHO 2008 standards.

Table 4: Comparison of the groundwater samples with the Iraqi, 2001 and WHO 2008 standards.
\begin{tabular}{|l|l|l|l|l|}
\hline Parameters & Q.S. 2009 & WHO 2008 & Ranged & Average \\
\hline $\mathrm{EC}(\mu \mathrm{s} / \mathrm{cm})$ & 1500 & 1530 & $4520-6650$ & 5532 \\
\hline $\mathrm{TDS}(\mathrm{ppm})$ & 1000 & 1000 & $2850-4330$ & 3656 \\
\hline $\mathrm{Ca}(\mathrm{ppm})$ & 150 & 75 & $309-526$ & 425 \\
\hline $\mathrm{Mg}(\mathrm{ppm})$ & 100 & 125 & $122-208$ & 158 \\
\hline $\mathrm{Na}(\mathrm{ppm})$ & 200 & 200 & $315-671$ & 469 \\
\hline $\mathrm{K}(\mathrm{ppm})$ & - & 250 & $10-110$ & 66 \\
\hline $\mathrm{Cl}(\mathrm{ppm})$ & 350 & 200 & $515-920$ & 697 \\
\hline $\mathrm{SO}_{4}{ }^{2-}(\mathrm{ppm})$ & 400 & $956-1696$ & 1396 \\
\hline
\end{tabular}

Conclusions:

A- The groundwater of the Dammam unconfined aquifer, Umaid Area - Muthanna Governorate are characterized by a meteoric water origin, neutral to slightly alkaline $\mathrm{pH}$ of excessively mineralized and slightly-brackish water. The common water type is $\mathrm{Ca}_{-} \mathrm{SO}_{4}$, where groundwater constituent is ordered as: $\mathrm{Ca}>\mathrm{Na}>\mathrm{Mg}(70 \%) ; \mathrm{Na}>\mathrm{Ca}>\mathrm{Mg}(30 \%) ; \mathrm{SO}_{4}>\mathrm{Cl}>\mathrm{HCO}_{3}(90 \%)$, but $\mathrm{Cl}>\mathrm{SO}_{4}>\mathrm{HCO}_{3}(10 \%)$.

B- Groundwater samples can be described as earthalkai water rich by $\mathrm{Ca}$ and $\mathrm{Mg}$ with increase alkalis and prevailing sulfate and chloride by $90 \%$, while the rest $10 \%$ represents an alkali water rich by Na with prevailing sulfates and chloride.

C- Multi-chemical processes were affected the groundwater chemistry in the study area. These are dissolution of carbonate and evaporate rocks, silicate weathering, the ionic exchange between clay minerals and groundwater as well as leaching by precipitation and irrigation returns flow. Fertilizers may provide additional ions to the groundwater aquifer. Dissolution is the common chemical process and there is no precipitation for any mineral species.

D- Groundwater- rock interaction in the Dammam aquifer is represented by the contribution of calcite and gypsum in supplying ions more than contribution of dolomite.

E- The main source of sulfate is dissolving of gypsum. The evaporation and oxidation-reduction are not effective process in the Dammam aquifer, where oxidizing sulfide is not detected in the study area.

F- The groundwater chemical analyses indicated that they are unsuitable for human drinking purposes. While, it is suitable to agricultural most of Fruit crops, most of vegetable and field crops. All groundwater samples are weak and suitable for all livestock, and are not suitable for poultry.

\section{REFERENCES}

[1] Al-Ansari, N.A., M.D. Jassim, H.A. Abbas, H.K. Sarkies, 1990. Economic and Strategic Importance of Groundwater in Iraq, Unpublished Report Ministry of Water Resources, p: 247 .

[2] Al-Azawi, 2016. Evaluation of groundwater utilization in AL-Salhubia area, southwestern of AL-Samawa city. Iraq, Ph.D. Thesis, , College of Science, University of Baghdad, unpublished, p: 240.

[3] Al-Shamari, A.N., 2006 . Hydrogeology and Hydrochemistry of Rehab Area /(South ) and (South-West) of Samawa City, unpub. M.Sc. Thesis, College of Science, University of Baghdad, 110p. (In Arabic)

[4] Al-Shamaa, A.M., 1993. Hydrogological and tectonic investigation of the southern part of the Western Desert (Qasra-Shbicha area) Ph.D. Thesis, College of science, Baghdad University, Iraq, (unpublished), (in Arabic). p: 200.

[5] APHA, 1998. Standard Methods of the Examination of Water and Wastewater .20th ed., Washington D.C., American Public Health Association.

[6] Cerling, T.E., B.L. Pederson and K.L.V. Damm, 1989. Sodium-Calcium ion exchange in the weathering of shales: implications for global weathering budgets. Geology, 17: 552-554.

[7] Collins, A.G., 1975. Geochemistry of oil field waters, Elsevier sci.pub.co. Amsterdam, p: 496.

[8] Crist, M.A. and M.E. Lowry, 1972. Groundwater resource of Natrona county wyming, A study of the availability and chemical quality of groundwater, Geological Survey Water Supply, Paper 1897, U.S. Government Printing office, Washington, p: 92.

[9] Detay, M., 1997. Water Wells. Implementation, Maintenance and Restoration. John Wiley and Sons, London, p: 379.

[10] El-Sayed, M.H., M.M. Abo El-Fadl and H.A. Shawky, 2012. Impact of hydrochemical Processes on Groundwater Quality, Wadi Feiran, South Sinai, Egypt, Australian Journal of Basic and Applied Sciences, 6(3): 638-654.

[11] Fetter,C.W., 1980. Applied hydrogeology, Charles Merrill pub. Co.A.bell and howell co. columbus, ohio, p: 488.

[12] Fisher, R.S. and W.F. Mulican, 1997. Hydrochemical evolution of sodium-sulfate and sodium-chloride groundwater beneath the Northern Chihuahuan desert, Trans-Pecos, Texas, USA. Hydrogeol. J., 10(4): 455-474.

[13] Gibbs, R.J., 1970. Mechanisms controlling world water chemistry; Science., 17: 1088-1090.

[14] Hem, J.D., 1985. Study and interpretation of the chemical characteristics of natural water (3rd ed.). U.S. Geological Survey Water-Supply Paper, 2254, 263p.

[15] Hounslow, A.W. 1995. Water Quality Data Analysis and Interpretation. Lewis Publishers, New York, p: 45-128.

[16] Hussain, Y.K., 2018. Evaluation of Groundwater of Al-Amaid area, AL-MUTHANA Governorate, ,IRAQ,Unpub.M.Sc.Thesis, College of Science, University of Baghdad

[17] Iraqi Standard (IQS), 2009, Iraqi Standard of drinking water. NO.417 ,modification No.2.

[18] Ivanov, V.V., L.N. Barbanov and G.N. Plotnikova, 1968. The main genetic types of the earth's crust mineral water and their distribution in the USSR. Inter. Geol. Cong. of 23rd. Sessions Czechoslovakia, p: 12.33.

[19] Jamil, A.K., 1977. Geological and hydrological aspects of Sawa lake, S. Iraq, Bull. Coll. Sci., 18(1): 221-253.

[20] Jankowski, J. and R.I. Acworth, 1997. Impact of debris-flow deposits on hydrogeochemical process and the development of dry land salinity in the Yass River catchment, New South Wales, Australia. Hydrogeol. J., 5(4): 71-88.

[21] Levy, D.B, and W.F. Kearney, 1974. Irrigation of native rangeland using treated waste water from in situ uranium processing J.Environ.Quality, $28: 208-217$.

[22] Matthess, G. 1982. The Properties of Groundwater. J. Wiley, New York, 406p.

[23] Maya, A.L. and M.D. Loucks, 1995. Solute and isotopic geochemistry and groundwater flow in the Central Wasatch Range, Utah.U.S.A. J. Hydrol., 172: 3159.

[24] Mayback, M., 1987. Global chemical weathering of surficial rocks estimated from river dissolved loads. Am. J. Sci., 287: 401-428. 
[25] Piper, A.M., 1944. A graphic procedure in the geochemical interpretation of water analyses, Transition, American Geophysical union, 25 : $914-923$.

[26] Sissakian, V., E. Ibrahim, F. Ibrahim and N. Al-Ali, 2000. Geological Map of Iraq 3rd edition (Scale 1: 1000000), GEOSURV, Bag. Iraq.

[27] Stiff, H.A., 1951. The interpretation of chemical water Analyses by means of Patterns', Jour. Petroleum Technology, v.3, no.10, Section1, 15-17; Section 2,3.

[28] Subramani, T., N. Rajmohan, L. Elango, 2010. Groundwater geochemistry and identification of hydrogeochemical processes in a hardrock region, Southern India, Environ Monit Assess., 162: 123-137.

[29] Thabit, J.M., A.I. Al-Yasi and A.N. Al-Shemmari, 2014. Estimation of hydrolic parameters and porosity from geoelectrical properties for fractured rock aquifer in Middle Dammam Formation at Bahr Al-Najaf Basin, Iraq. Iraqi Bulletin of Geology and Mining,10(2): 41-57.

[30] Todd, D.K., 2007. Groundwater Hydrology (2nd edition).John Wiley and Sons, Third Reprint. Inc. India, p: 535.

[31] WHO, 2008. Guidelines for drinking water quality. 3rd ed., vol.1, recommendations, Geneva, p: 516. 